Article

\title{
Sustainability: A Public Policy, a Concept, or a Competence? Efforts on the Implementation of Sustainability as a Transversal Competence throughout Higher Education Programs
}

\author{
Jorge Membrillo-Hernández *, Vianney Lara-Prieto (D) and Patricia Caratozzolo \\ Institute for the Future of Education, School of Engineering and Sciences, Tecnologico de Monterrey, \\ Monterrey 64849, Mexico; vianney.lara@tec.mx (V.L.-P.); pcaratozzolo@tec.mx (P.C.) \\ * Correspondence: jmembrillo@tec.mx
}

Citation: Membrillo-Hernández, J.; Lara-Prieto, V.; Caratozzolo, P. Sustainability: A Public Policy, a Concept, or a Competence? Efforts on the Implementation of Sustainability as a Transversal Competence throughout Higher Education Programs. Sustainability 2021, 13, 13989. https://doi.org/10.3390/ su132413989

Academic Editors: Arturo Molina Gutiérrez, Jane-Frances Agbu, Ebba Ossiannilsson and María Soledad Ramírez Montoya

Received: 1 November 2021 Accepted: 10 December 2021 Published: 18 December 2021

Publisher's Note: MDPI stays neutral with regard to jurisdictional claims in published maps and institutional affiliations.

Copyright: (C) 2021 by the authors Licensee MDPI, Basel, Switzerland. This article is an open access article distributed under the terms and conditions of the Creative Commons Attribution (CC BY) license (https:/ / creativecommons.org/licenses/by/ $4.0 /)$.

\begin{abstract}
The concept of sustainability emerged globally in the 1987 Brundtland Report. Initially, it comprised three dimensions: environmental, social, and economic. Over time, sustainability became a global necessity that led to the establishment in 2015 of the 17 Sustainable Development Goals (SDGs), so that sustainability became a public policy of extreme urgency. Thirty-four years later, there is an imperative need to expand the original concept not in a public policy but in a competence that graduates of higher education develop, regardless of their studied academic program. We propose sustainability as a transversal competence. Our work describes the path that a higher education institution in Mexico, Tecnologico de Monterrey, has followed to accomplish this task. The new educational model Tec21 based on challenge-based learning experiences has a focus on the development of sustainability competences and actions ownership towards solving the problems described in the 17 SDGs. Our proposed definition for the sustainability transversal competence is: "The student possesses the knowledge, skills and attitudes necessary for the successful performance of the task and the resolution of problems related to the challenges and opportunities for sustainability in today's world". Thus, education is both an objective and a means to achieve all the other SDGs.
\end{abstract}

Keywords: higher education; educational innovation; competences; socially oriented education; sustainability; challenge-based learning; education 4.0

\section{Introduction}

Sustainability would seem like a modern concept that encompasses many ideas; however, its meaning has evolved over time, the most common is to associate it with something that lasts, is perennial, or that by its nature remains present, without consumption of something that would be harmful externally, applying this in many areas of knowledge or society. In fact, the term sustainability has become popular in policy-oriented research as an expression of what public policies ought to achieve [1]. The modern sciences of the 21st century have taken the concept of sustainability as a necessity, something that is required for the coexistence of the Earth's biosphere and human civilization [2].

It was in 1987 when the comprehensive description of sustainability was established in the document "Our Common Future" (also known as "the Brundtland report") and defined as "meeting the needs of the current generation without compromising the ability of future generations to satisfy their needs" [3]. From that moment on, scholars established three interconnected domains that would be the dimensions of sustainability: the environment, the economy, and the society [2]. However, today in 2021, some experts have included other domains that participate in sustainable development (SD): culture, the economics of technology, and politics [3,4]. 


\subsection{Literature Review}

Starting in 2007, an intense discussion began about what competencies academic programs should develop, and this is shown by Barth et al. in their work [5]. The discussion has led to the design of reference frameworks for sustainability key competences (SKCs), with the aim of including it in academic programs, such as the one reported in 2011 by Wiek et al. [6]. In 2012 Rieckmann raised an important research question: which individual key competencies are crucial for understanding the central challenges of world society and for shaping it in terms of sustainable development and thus should be fostered through university teaching and learning? [7]. That same year, Barth and Rieckmann published a work where they analyzed the extent to which a program implemented in Ecuador has positive effects on transformative changes towards a sustainable university. The results of this case study thus highlight the potential benefits of the education for sustainable development (ESD) academic programs in terms of their relevance for initiating individual learning processes [8].

Despite this emerging convergence, a state of clarity between sustainability competencies had not yet been reached until 2017, when Brundiers and Wiek published their study on teaching and learning professional skills in sustainability [9]. Since the first postgraduate programs on sustainability issues started at the universities of Harvard, Arizona State, Lund, Maastricht, Leuphana, Tokyo, Stellenbosch, and the Technique of Catalonia, the number of academic programs on sustainability in higher education has increased considerably. In the United States alone, 2361 have been reported in 872 academic institutions [10]. A projection study suggests a 9\% increase in the sustainability labor market by 2024 [11]. In 2018, the very interesting study of Aleixo et al., in Portugal, showed that the universities were mainly engaged in the social dimension of sustainability. The study aimed to provide guidance to support institutions in the transition process towards sustainability [12]. The study by Cebrián, in 2019, reviewed existing theoretical frameworks in sustainability competencies and identified suitable evaluation strategies and instruments for sustainability competencies assessment in the context of ESD. The study also suggested pathways for further research and practice based on a systematic literature review [13].

Two studies from 2020 showed progress in the conceptualization and understanding of sustainability competencies. On one side, Aleixo et al. showed that only a few courses address explicitly at least one of the Sustainable Development Goals (SDGs). This study raised awareness so that the higher education institutions can take responsibility and engage more in SDGs [14]. On the other side, Birdman et al. investigated the experiences of students in EBL through a key competence lens, combining student self-perceptions, instructor reflections, and in vivo observations [15].

During the first months of 2021, three important studies provided interesting analyses to the understanding of sustainability in the academic field. The first study by Aleixo et al. aimed to provide guidance to support institutions in the transition process towards sustainability. This study analyzed the engagement level of universities in the social, economic, and institutional dimensions of sustainability [16]. The second study by Redman et al. structured the field of sustainability competency assessment and provided a criteria-based overview of the currently used tools, through a systematic literature review of 75 studies that detail the use of an assessment tool [17]. Finally, the third study by Pálsdóttir and Jóhannsdóttir identified competencies that should be fostered through university teaching and learning, and showed that twelve key competencies are crucial for sustainable development, including those for systemic thinking, anticipatory thinking, and critical thinking [18].

All these studies reveal that sustainable competences are not acquired naturally in the facilities of teaching-learning spaces. Therefore, strategies for ESD such as Challenge-Based Learning (CBL) are suitable to transform the student into a conscious individual with the capacity to carry out actions for the benefit of sustainability, but it is not clear whether sustainability alone is a competence or not. 


\subsection{Sustainability as a Public Policy}

Sustainability as a public policy that responds to an urgent need for action by the governments of the world to take care of the environment and society in general became a concept, promoted for the first time, in 1992 by UNESCO through the program "EDS Global". The increasing urgency to raise awareness, and the importance of knowledge transfer led UNESCO to implement the "United Nations (UN) Decade for ESD 2005 to 2014" and later the World Program of Action on ESD, always with the goal that global problems such as climate change urgently require a change in our lifestyles and a transformation in the way we think and act. On 25 September 2015, the UN General Assembly adopted the 2030 Agenda for Sustainable Development [19]. In this document the 17 SDGs were established as public policies for every government. The SDGs describe the main development challenges for humanity. The goal of the 17 SDGs is to ensure a sustainable, peaceful, prosperous, and equitable life on earth for all, now and in the future. Without a doubt, education is the engine, the vehicle, and the fundamental basis of social transformation, since to achieve this change, we need to acquire new skills, values, and attitudes that lead to more sustainable societies. The advent of the Fourth Industrial Revolution (4IR) is changing the world due to new technologies that combine the physical, digital, and biological worlds, and dynamically impact disciplines, economies, and industries [20]. A fusion of these last notions produces a definition for sustainable development in the 4IR, which is "the use of technologies to combine the physical, digital, and biological worlds to improve the lives of citizens who live in harmony with the environment" [21].

Education systems must respond to this pressing need by defining learning objectives and relevant learning content, introducing pedagogies that empower learners, and urging their institutions to include sustainability principles in their management structures. Even education is explicitly formulated as a standalone goal: SDG 4. Education is both a goal and a means to achieve all the other SDGs $[9,21]$. It is not only an integral part of sustainable development, but also a key enabler of it. That is why education represents a fundamental strategy in achieving the SDGs.

After the analysis of the context of the implementation of educational programs in sustainability, and proceeding to the publication of the SDGs (prior to 2015) and even establishing the 8 SKCs [22], which are very similar to the graduation competences of the higher education students in these programs, we hypothesized that sustainability could be taken as a competence in itself, with its own definition that could be a cross-competence to all university teaching programs, which could have its own compliance and evaluation indicators. For this, we analyze by means of a retrospective method the implementation of academic programs at Tecnologico de Monterrey, adopting sustainability as a competence, and we analyze the results obtained so far.

\section{Materials and Methods}

The general purpose of this research was to investigate the establishment of sustainability not only as a concept as part of a course, but as a transversal competence in all the careers of a higher education institution. Additionally, those that have been considered to establish a specific Sustainable Development Engineering program. The Tec21 educational model established in our institution since 2014 uses the challenge-based learning educational framework [23-25] in essentially two formats: $i$-Week and $i$-Semester, which have served us to implement sustainability as a competence.

(A) $i$-Week. For both formats of didactic CBL experiences, undergraduate students of various careers from the Faculty of Engineering and Sciences of the Tecnologico de Monterrey, a university of Higher Education in Mexico, were auto-enrolled. Every odd semester a new activity could be chosen. The study period of this research is from 2015 to 2020 (five different periods of $i$-Week). Interestingly, in the first 2 years (2015 and 2016), a sustainable perspective was not involved, only conceptual information, in contrast from 2017 to 2021, when a strong sustainability component was added as shown in Table 1. 
Table 1. Transformation of CBL strategies into activities to develop skills in sustainability.

\begin{tabular}{|c|c|c|c|}
\hline Educative Experience & Original Challenge & Sustainability Challenge & $\begin{array}{l}\text { Number of } \\
\text { Students }\end{array}$ \\
\hline i-Week & $\begin{array}{l}\text { ELARA. Designing an } \\
\text { electrical and electronic } \\
\text { system that would allow } \\
\text { to communicate in the } \\
\text { Campus }\end{array}$ & $\begin{array}{l}\text { ELARA. Designing an electrical and electronic system that } \\
\text { would allow communication to be brought to isolated } \\
\text { communities in the country, where no electricity is present. } \\
\text { One key step of this challenge was the implementation of } \\
\text { solar panels to provide enough energy for all the required } \\
\text { devices. In one week, students were challenged to apply } \\
\text { all their knowledge. }\end{array}$ & 75 \\
\hline i-Week & $\begin{array}{l}\text { PROFEPA. Reviewing a } \\
\text { company for a week } \\
\text { detecting procedures to } \\
\text { protect the environment } \\
\text { and compliance with } \\
\text { current standards }\end{array}$ & $\begin{array}{l}\text { PROFEPA. Reviewing a company for a week detecting } \\
\text { procedures to protect the environment and compliance } \\
\text { with current standards.An additional challenge was } \\
\text { included where their studies of industrial ecology, } \\
\text { environmental legislation, and ethics were put to the test } \\
\text { in an exercise of high demand in a real work environment. }\end{array}$ & 80 \\
\hline i-Week & $\begin{array}{l}\text { ZIKLUM. The strategy is } \\
\text { to find new uses for } \\
\text { Tetra-Pak packaging in } \\
\text { such a way as to avoid the } \\
\text { proliferation of landfills } \\
\text { and find innovative ideas } \\
\text { for the integral } \\
\text { management of solid } \\
\text { waste }\end{array}$ & $\begin{array}{l}\text { ZIKLUM. The strategy is to find new uses for Tetra-Pak } \\
\text { packaging in such a way as to avoid the proliferation of } \\
\text { landfills and find innovative ideas for the integral } \\
\text { management of solid waste. }\end{array}$ & 120 \\
\hline$i$-Week & $\begin{array}{l}\text { XOCHIMILCO. To design } \\
\text { a knowledge-based } \\
\text { awareness campaign to } \\
\text { preserve the World } \\
\text { Heritage City of } \\
\text { Xochimilco }\end{array}$ & $\begin{array}{l}\text { To find a way to get the message across. A new addition } \\
\text { for CBL was added one year after the start of this } \\
\text { challenge that involves biodiversity concepts and water } \\
\text { quality testing and designing a sustainable city. }\end{array}$ & 100 \\
\hline$i$-Semester & $\begin{array}{c}\text { Design and chemical } \\
\text { structure and use of } \\
\text { blisters for pharmaceutical } \\
\text { products }\end{array}$ & $\begin{array}{l}\text { Structure and use of blisters for pharmaceutical products, } \\
\text { disposal, and life-cycle analysis. }\end{array}$ & 100 \\
\hline
\end{tabular}

\begin{tabular}{|c|c|c|c|}
\hline$i$-Semester & $\begin{array}{l}\text { Quantification of the } \\
\text { Carbon footprint of a } \\
\text { training partner company } \\
\text { as an exercise for the use } \\
\text { of methodology }\end{array}$ & $\begin{array}{l}\text { Quantification of the carbon footprint of a training partner } \\
\text { company giving advises in the ways of decreasing energy } \\
\text { consumption. }\end{array}$ & 50 \\
\hline$i$-Semester & $\begin{array}{l}\text { How to make a } \\
\text { photovoltaic panel, } \\
\text { structure, and analysis of } \\
\text { energy transformation }\end{array}$ & $\begin{array}{l}\text { How to make a photovoltaic panel, structure, and analysis } \\
\text { of energy transformation, and implementation in a rural } \\
\text { community. }\end{array}$ & 47 \\
\hline$i$-Semester & $\begin{array}{l}\text { Chemical structure of oil } \\
\text { from a production } \\
\text { industrial plant }\end{array}$ & $\begin{array}{l}\text { Chemical structure of oil from a production industrial } \\
\text { plant and further studies to use a biofuel for rural } \\
\text { communities. }\end{array}$ & 47 \\
\hline$i$-Semester & $\begin{array}{l}\text { Determine the amount of } \\
\text { methane produced in the } \\
\text { wastewater treatment } \\
\text { plant }\end{array}$ & $\begin{array}{l}\text { Determine the amount of methane produced in the } \\
\text { wastewater treatment plant and establish strategies for its } \\
\text { use or disposal. }\end{array}$ & 26 \\
\hline
\end{tabular}

It is important to note that the $i$-Week no classes were held at the university for a week to allow students to concentrate on the activities of the five days if the $i$-Week. A minimum of three expert faculty members (teaching related subjects) were in charge of the design of the challenge and all its associated activities. The $i$-Week was divided into three steps: 
involvement (reading, planning of activities, and determining the schedule of actions), development (carrying out planned activities, innovative actions), and finally discussion and conclusions (where all students compare their results and can improve the conclusions of others).

(B) $i$-Semester. A 14-week challenge-based education period. During these experiences, the challenge was carried out with strategic training partners [26] and various evaluation techniques were used. The study period of this research was from 2015 to 2021 (five different periods of $i$-Semester; Table 1) [21].

School environments and students. For both strategies, $i$-Week and $i$-Semester, a research study was carried out on the impact on the learning experience and satisfaction surveys were established for students and faculty, including questions on sustainability. The research was conducted once a year during the fall semester of 2015, 2016, 2017, 2018, 2019, and 2020. The number of students in each year ranged from 15 to 71 undergraduate students for this study. Students were always grouped into at least four teams each year.

Instructional design. Participating faculty members were trained during the summer prior to each research semester (always in the fall) through a 20-h course in which they discussed suitable strategies to implement appropriate teaching techniques for the CBL to become mentors or coaches, rather than teachers from a normal classroom, as the goal is to cover course topics by solving challenges. Faculty met with staff from training partners to determine challenges to solve. It is important to note that the challenges were decided based on the professional competencies for a graduate (based largely on sustainable competencies). Some challenges with a sustainable perspective were, among others: (a) comprehensive management of pruning and solid resistance within the production plant, (b) structure and use of double blister packs for pharmaceutical products, elimination and life cycle analysis, (c) use of food oil wastewater in the cafeteria of the production plant to make some useful fuel, (d) determine the amount of methane produced in the wastewater treatment plant and establish strategies for its use or disposal, (e) quantification of the Carbon Footprint of a company training partner giving advice on ways to reduce energy consumption, and (f) design and construction of a photovoltaic panel, structure, and analysis of energy transformation and implementation in a rural community.

\section{Results}

ESD empowers students of all ages with knowledge, but it can also become a skill that may be part of all the undergraduate programs offered by higher education institutions. In this way, undergraduate students can acquire the skills, values, and attitudes to address the interconnected global challenges that the SDGs aim to solve, including climate change, environmental degradation, loss of biodiversity, poverty, and inequity. For this reason, institutions such as the Tecnologico de Monterrey in Mexico have developed a framework for the implementation of sustainability as a transversal axis and have walked towards the implementation of it as a graduation competence that prepares students to find solutions to the challenges of today and the future, regardless of the studied discipline.

\subsection{Framework for Education in Sustainability at the Tecnologico de Monterrey, Mexico}

Sustainability is conceptualized and elaborated differently by academia, professional associations, and government organizations. Therefore, it is necessary to define what the capacity for "sustainable thinking" implies from the technological, environmental, and social perspective, for higher education. In the last ten years, which are the focus of this study, there have been many transformative paradigm shifts related to caring for the environment, climate change, the circular economy, and the responsibility of society. Thanks to this paradigm shift, we can talk about decarbonization policies for 2030 or Net Zero Carbon strategies for 2050. The transformation has made education change from a model based on the "disciplinary knowledge on sustainability", towards an interdisciplinary and transversal approach of "sustainable thinking". 
To ensure "sustainable thinking" among students, it is necessary to promote and develop the concept of sustainability towards a transversal competence with strategies like those used for the development of critical thinking, including some actions and experiences within the classroom that allow students to:

(1) Develop higher order cognitive skills

(2) Develop attitudes of commitment, initiative, and leadership

(3) Learn in an active educational environment such as challenge-based learning (CBL), project-based learning, and/or experiential learning, which includes assessment of competences, and which promotes not only learning but also civic and ethical development.

The paradigm shift related to sustainability has manifested itself gradually in the last ten years in such a way that we went from the passive learning approach, to the active participation and commitment of the students in their own learning process; from the design of projects with indiscriminate technological development, to challenges with social and environmental responsibility; from the mitigation of environmental and social impacts, to prevention; from the design of projects with indiscriminate technological development, to challenges with social and environmental responsibility; and finally to consider sustainability as an abstract concept for its full incorporation as a competence of "sustainable thinking". Some of the components of this paradigm shift, based on the research methodology of the present study, are described in Table 2.

Table 2. Some components of the paradigm shift in sustainability, experienced at Tecnologico de Monterrey.

\begin{tabular}{|c|c|}
\hline Before (2011-2015): & After 2015 (2021): \\
\hline $\begin{array}{l}\text { Disciplinary teaching (curriculum based on } \\
\text { watertight environments without } \\
\text { communication with other subjects or courses) }\end{array}$ & $\begin{array}{l}\text { Interdisciplinary learning environments } \\
\text { (curriculum based on interconnected blocks) }\end{array}$ \\
\hline Problem oriented and project-based learning & Challenge-based learning \\
\hline $\begin{array}{c}\text { Teacher-centered instruction (lectures, } \\
\text { laboratory assistants) }\end{array}$ & $\begin{array}{l}\text { Student-centered (collaborative, personalized, } \\
\text { and self-paced learning) }\end{array}$ \\
\hline $\begin{array}{l}\text { Closed system cases and exercises with preset } \\
\text { and known solutions }\end{array}$ & $\begin{array}{c}\text { Open complex systems and ill-defined } \\
\text { problems, with ambiguities and volatility in its } \\
\text { elements }\end{array}$ \\
\hline Disciplinarily exercise solving & $\begin{array}{l}\text { Challenge-solving with social orientation } \\
\text { based on interdisciplinary approaches }\end{array}$ \\
\hline Technological feasibility & Economic and social responsibility \\
\hline $\begin{array}{l}\text { Technological, economical, and social growth } \\
\text { indicators }\end{array}$ & $\begin{array}{l}\text { Sustainable development and economic, social, } \\
\text { and environmental impacts }\end{array}$ \\
\hline
\end{tabular}

\subsection{Sustainability Thinking as a Competence}

Citizens trying to establish a sustainable world must have certain key competencies to be able to engage constructively and responsibly with today's complex challenges. These competencies are transversal, multifunctional, and independent of the context. UNESCO declared eight key competencies for sustainability, which are: systems thinking, anticipatory, normative, strategic, collaboration, critical thinking, self-awareness, and integrated problem solving. The first five competencies are the same as those declared in Sustainable Thinking. UNESCO adds three more:

Critical thinking. Ability to question norms and practices, reflect on one's own values and actions, and position oneself in the discourse of sustainability.

Self-awareness. The ability to reflect on one's role in society and be aware of one's actions and feelings.

Integrated troubleshooting. The ability to apply problem-solving frameworks to complex sustainability problems and develop viable solution options, integrating the other seven competencies. 
We would like to establish here that in our analysis and in parallel to the UNESCO proposal, the sustainable thinking competence involves having the knowledge, skills, and attitudes necessary for successful task performance and problem solving related to realworld sustainability challenges and opportunities [27]. This competence is made up of five sub-competences: systems thinking, anticipatory competence, normative competence, strategic competence, and interpersonal skills. These five sub-competences must be integrated to generate knowledge and action for sustainability. If students develop skills in the five components of the Sustainability Thinking competency, they will: analyze a sustainability problem from a holistic perspective; assess a problem and its context holistically with respect to sustainability; build hands-off scenarios on how the problem might develop in the future; visualize future sustainable states in contrast to non-intervention scenarios; and finally, create intervention strategies to avoid undesirable scenarios and make sustainability visions a reality (Table 3).

Table 3. The Sustainability Thinking competence and its sub-competences, concepts, and methods.

\begin{tabular}{|c|c|}
\hline Sub-Competences & Sustainability Thinking \\
\hline Systems Thinking & $\begin{array}{l}\text { The ability to analyze sustainability problems cutting across different } \\
\text { domains and scales, thereby considering agents, cause-effect structures, } \\
\text { cascading effects, inertia, feedback loops, etc. }\end{array}$ \\
\hline Future Thinking & $\begin{array}{l}\text { The ability to anticipate how sustainability problems and solutions might } \\
\text { evolve over time, considering alternative development pathways for } \\
\text { current systems and crafting new and different pictures of the future. }\end{array}$ \\
\hline Values Thinking & $\begin{array}{l}\text { The ability to collectively map, specify, apply, reconcile, and negotiate } \\
\text { sustainability values, principles, goals, and targets. }\end{array}$ \\
\hline Strategic Thinking & $\begin{array}{l}\text { The ability to design and implement transformational (systemic) } \\
\text { intervention and transition strategies toward sustainability. }\end{array}$ \\
\hline Interpersonal Skills & $\begin{array}{c}\text { The ability to motivate, enable, and facilitate collaboration in sustainability } \\
\text { efforts. }\end{array}$ \\
\hline \multicolumn{2}{|r|}{ Concepts } \\
\hline Systems Thinking & $\begin{array}{c}\text { Variables/indicators, clusters, sub-systems, ontologies } \\
\text { Cause-effect chains, cascading effects, feedback loops, delays }\end{array}$ \\
\hline Futures Thinking & $\begin{array}{l}\text { Temporal terms, phases, states, continuity, and nonlinearity } \\
\text { Risk, precaution, and intergenerational equity }\end{array}$ \\
\hline Values Thinking & $\begin{array}{l}\text { Sustainability goals, targets, and thresholds } \\
\text { Concepts of justice, fairness, responsibility, etc. }\end{array}$ \\
\hline Strategic Thinking & $\begin{array}{c}\text { Success factors, viability, feasibility, effectiveness, and efficiency. } \\
\text { Adaptation and mitigation }\end{array}$ \\
\hline Interpersonal Skills & $\begin{array}{l}\text { Concepts of leadership, cooperation, and empathy } \\
\text { Concepts of solidarity, ethnocentrism, nationalism, etc. }\end{array}$ \\
\hline \multicolumn{2}{|r|}{ Methods } \\
\hline Systems Thinking & $\begin{array}{c}\text { Qualitative problem/system analysis } \\
\text { Quantitative modeling }\end{array}$ \\
\hline Futures Thinking & $\begin{array}{l}\text { Scenario methodology } \\
\text { Forecasting from statistical and simulation models }\end{array}$ \\
\hline Values Thinking & $\begin{array}{l}\text { Impact assessment methods } \\
\text { Risk analysis }\end{array}$ \\
\hline Strategic Thinking & $\begin{array}{l}\text { Intervention design } \\
\text { Constructive governance design }\end{array}$ \\
\hline Interpersonal Skills & Negotiation Conflict resolution \\
\hline
\end{tabular}

Achieving the development of sustainable thinking requires close interdisciplinary collaboration with researchers from other disciplines and with stakeholders in government, business, and civil society. For this reason, the challenge of establishing a single definition of sustainable thinking as a competence is the result of interdisciplinary work over a long period. Table 3 explains the sub-competences that make up sustainable thinking, the concepts they use, and the methods they use. 


\subsection{Framework Development for Education in Sustainability at the Tecnologico de Monterrey}

Then we analyzed the strategies, initiatives, and experiences that were carried out in our institution during the last ten years in reference to the objective of incorporating sustainability in undergraduate study programs (Figure 1). It is interesting to observe that in parallel, some key articles in the discussion of the role of sustainability in education coincided with the actions carried out in our university. In this way, we were able to find not only multiple contemporary developments that coincide in ideas and approaches, but also several crossings of activities and experiences in common. A brief comparative analysis is depicted in Figure 1, and the development is more detailed in the paragraphs that follow.

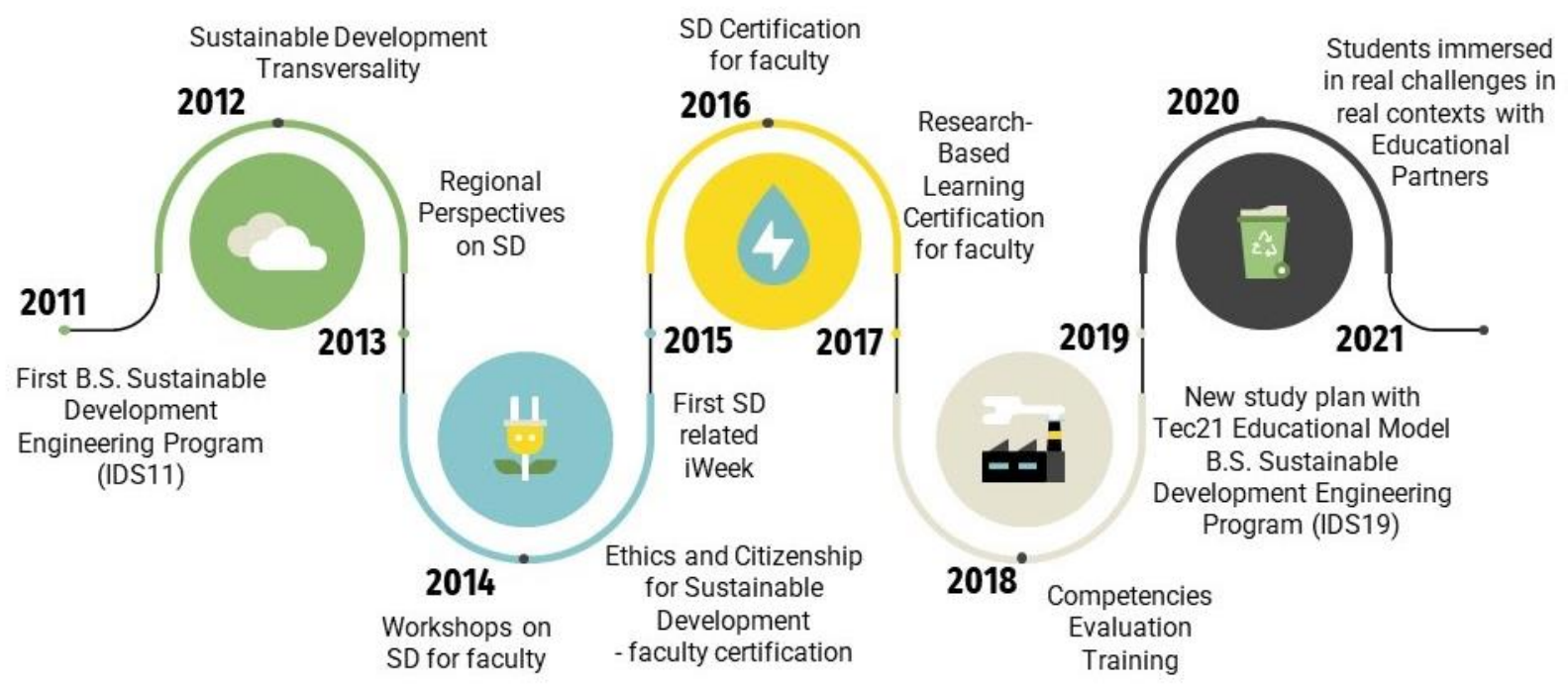

Figure 1. Outstanding events in the implementation of sustainability in the educational programs of Tecnologico de Monterrey in the last 10 years.

2011. First undergraduate Sustainable Development Engineering (IDS) program at our university. The commitment to work for the sustainable development of our world, the curriculum was planned taking into account the knowledge, skills, and values that graduates should develop. During that year, an investigation was carried out aligned with the ESD program, reflecting on the appropriate pedagogical methods to teach sustainability, highlighting the need for reflective practice, ethical dialogue, and the implementation of knowledge for a positive impact of our environment [28].

2012. Mainstreaming of SD as a transversal competence. SD was implemented in a transversal way in the different schools. Although the IDS program was launched in the Faculty of Engineering, it became clear that this competence must be developed regardless of the discipline or academic program. The first step was to train teachers in this mindset and begin a reflective process to embrace it and create new possibilities in the educational context. Engineering activities can positively impact environmental management [29]; however, the cross-cutting dimension of sustainability should be emphasized.

2013. Regional perspectives on SD. Based on the RIO + 20 report and the initiative of researchers from Tecnologico de Monterrey to create a scientific community for "sustainable development" in Latin America, the following research questions were established:

Are there organized communities and networks in the region?

What is the scope of transnational collaboration at the scientific level?

Have these communities been able to influence decision-making?

How are these communities related to those in other regions and globally?

What strategies and policy actions at the institutional level are suggested?

2014. Skills Workshops in SD (Training of our faculty). The institution held a 40-h workshop at Arizona State University to train its faculty. The instructors were the authors 
of the most important manuscripts of that time [30,31]. The program discussed existing methods of developing students' competences in solving sustainability problems and familiarizing teachers with key sustainability competences (concepts and methods) and professional activities that graduates will be able to execute.

2015. First $i$-Week related to SD. In October 2015, the first experience with the CBL approach was carried out at the 26 Tecnologico de Monterrey campuses, known as $i$-Week. For 5 days, all students stop their courses to do challenging activities for all academic programs. The challenges designed by the professors can be developed on campus, off campus or in conjunction with an external training partner that can be a company, industry, or social organization, in such a way that, for five days, students are exposed to real situations to develop a solution strategy. Specific skill assessments, each based on rubrics, checklists, knowledge tests, or challenge-based learning assessments were conducted through written progress reports and oral presentations.

2016. Transversal Sustainable Development-Certification for faculty. In 2016, a new certification for faculty was created, Transversal Sustainable Development, which consisted of faculty training so that they could incorporate experiences, activities, and projects related to SD in any course of the discipline. The course consisted of a 4-week instruction with specialists, then 8 weeks of design, where each professor worked on their own, designing the experience for their subjects, and finally a pilot implementation in an experimental group. The activities were evaluated with three instruments: rubric, observation guide, and exit survey to the students. Finally, the professors who successfully accredit the course were able to implement the experience in their courses, which received the Sustainable Development Support Project attribute. This initiative was the first to incorporate the Transversal Sustainability competence in all curricular programs, and from that year on, this new attribute was incorporated into the courses, along with the existing ones, which were Transversal Ethics and Transversal Citizenship.

2017. Research-Based Learning (RBL): Faculty Certification and Student Assessment. In 2017, the Tecnologico de Monterrey incorporated a new learning approach to its set of teaching techniques: RBL. It aims to promote and develop the competences of students related to the practice of research and benefit students through linked activities. This technique involves the application of learning and teaching strategies to awaken students' interest in knowledge and the main problems facing society, broadening their perspectives, and focusing on their areas of study. By its very nature, the RBL was ideal for engaging students in the sustainable thinking competence from the beginning of their studies, in parallel with the acquisition of basic investigative skills, such as searching for information in authoritative and reliable sources, critical analysis of knowledge, and the development of oral knowledge and written communication skills to be able to present the results. By incorporating this technique into selected courses from the IDS curriculum, students were not only able to learn from new discoveries and research methods in sustainability, but also to become involved in the research processes themselves, thus participating in the search for new knowledge and research. In the application of research to practice, students raised the level of quality of the projects and initiatives in which they participated [32,33].

2018. $40 \mathrm{~h}$-Workshop of Technical Update-Training for faculty. During 2018, Tecnologico de Monterrey added some specific courses on the subject of sustainability to its portfolio of Upskilling / Reskilling workshops for teachers.

2019. New Undergraduate IDS Program. The objective of the IDS program is to prepare professionals who are involved in the generation and efficient use of energy, the protection of natural resources, and the identification of innovative business opportunities. Graduates generate and implement comprehensive investment proposals in energy issues, sustainable use of resources, and waste management, considering the need to generate wealth, including aspects of social responsibility and public policies.

2020. Real challenges in real contexts. In March 2020, the appearance of COVID19 forced Tecnologico de Monterrey to abruptly adopt social distancing and quarantine measures, which made compliance with the Educational Framework 4.0 much more chal- 
lenging. However, these challenges created new opportunities: several collaborators of the institution contacted their colleagues in other countries, to discuss how to ensure that students had the opportunity to live an international experience within the Educational Framework. 4.0 and with the aim of developing its competence in sustainability. The result was an international cooperation project [34].

2021. Interdisciplinary Approach: Creation of the SOI-STEM Research Group. The project "Socially oriented STEM interdisciplinary education for the 21st century" is a collaboration between interdisciplinary experts in STEM education, social sciences, humanities, and arts. It aims to foster a socially oriented interdisciplinary vision in STEM education to meet the challenges of the 21st century through interdisciplinary education that promotes sustainability, diversity, equity, and inclusion. The proposed project is relevant for stakeholders and the general community since it explicitly addresses some of the needs highlighted by international authorities and experts, such as improving inclusion in STEM education and societies' understanding of science and technology in the Latin American context.

"Oriented to society" implies a global impact on the well-being of the community, in the formation of responsible, upright professionals, agents of change who possess both technical skills and social and ethical awareness. It recognizes the social complexity of problems so that meaningful solutions to urgent problems such as climate change or irregular settlements arise from socio-technical ecosystems that combine theory, data, and technology. The guideline for planning and meeting the objectives of this Interdisciplinary Research Group will be the UN SDGs.

\subsection{The New Educational Model Tec21}

In the summer of 2013, the Tecnologico de Monterrey began to implement the Tec21 Educational Model (Figure 2) [35,36]. There are four fundamental pillars of the model: (a) CBL; (b) flexibility; (c) trained and inspiring teachers; and (d) comprehensive and memorable educational experiences [21,23-26,29]. The implementation of experiential learning experiences such as $i$-Week and $i$-Semester which expose students to challenging experiences with or without the support of training partners [18] were initially without a sustainability perspective and were maintained in the conceptual development of activities. However, with the evolution of sustainability as a transversal axis to all careers, the experiences of CBL were modified accordingly creating in the students a sustainability competence in any field of the three dimensions of sustainability (environmental, economic, and social). Table 1 indicates the transformation of some activities such $i$-Week and $i$-Semester that have been changed to add a sustainability component and gradually create the sustainability competency. In all cases, the training partners approved and promoted the challenges for a more sustainable perspective. It is worth mentioning that subjects available to all the study programs in the Tec21 model include (A) Climate Change and Energy Use, (B) Biomimicry and Sustainability, (C) Natural Resources and Climate Change, and (D) Circular Economy. In addition, the institution created a global initiative for the implementation, review, and fulfillment of the SDGs, whose direction creates a list of monitoring indicators. Finally, a Vice-Rector's Office for Dignity and Inclusion and Sustainability was created that reviews and implements actions to ensure equity and sustainability of the administrative, academic, and social processes of the entire university. 


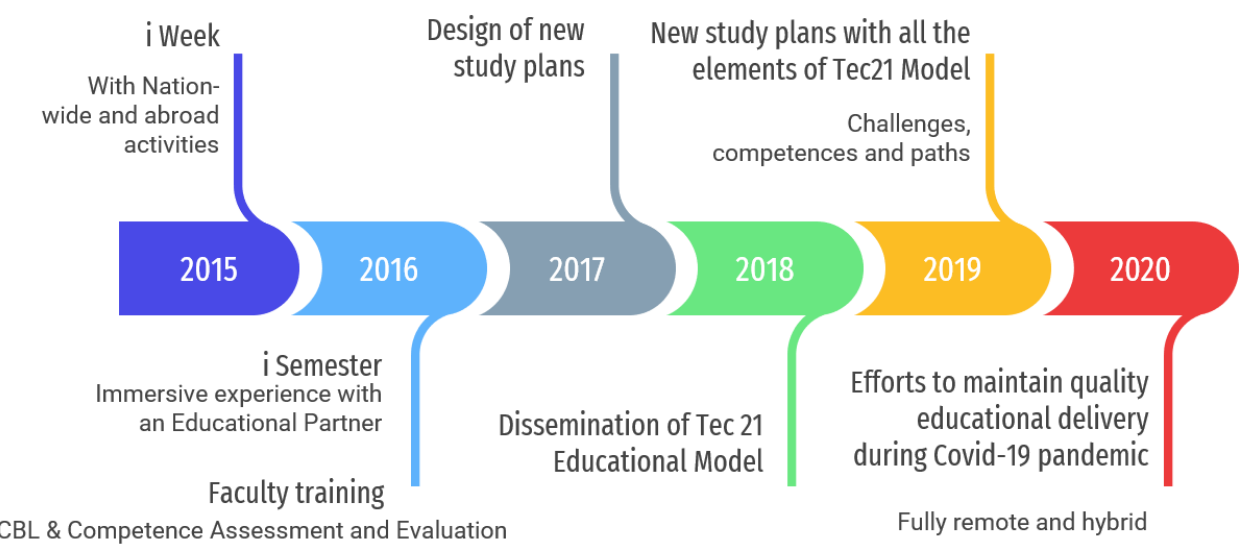

Figure 2. Development timeline of Tec21 Educational Model and its elements.

\section{Discussion}

In this manuscript we describe the efforts of an educational institution of higher education for the implementation of sustainability as a transversal axis in all academic and administrative activities, the transformation of experimental activities and the implementation of subjects and courses that create a sustainable vision of the planet, in a global way. We live in a rapidly changing world where innovation and transformation are the common factors. Graduates must have a solid background in terms of knowledge and skills relevant to their discipline of study, but also a set of competences that allow them to build solutions to new problems. Our world is facing the transition to the 4IR (Industry 4.0), moving from automation to interconnected cyber and physical systems that communicate and analyze data to make decisions and deploy actions to optimize systems. Education 4.0 arises within the complex context of Industry 4.0 and Web 4.0. Education 4.0 implies learning by doing, experimenting, and integrating emerging technologies [37]. Education 4.0 is still emerging and involves technologies based on Artificial Intelligence for adaptive learning according to the student's profile [38]. We are transitioning from Education 3.0 which involves active learning, web-driven technologies, interdisciplinarity, and stepping outside the confines of the classroom. The main concepts of Education 4.0, and differences with Education 3.0, are massive connectivity and interaction between humans and machines through artificial intelligence [39]. New technologies require new pedagogical approaches, and, with them, the roles of students and teachers also evolve. Most of today's undergraduate students have grown up with the Internet and digital tools. In this context, students become protagonists of their own learning itinerary, with active participation, more autonomy, flexibility, and personalized rhythm according to the profile of each student [40]. The contribution of higher education to the economy and the development of society is evident. More recently, the contribution of universities and their graduates to the sustainability of our communities has been recognized [41]. Universities have the responsibility to train professionals who are aware of the needs of our world and are committed to contributing their potential to the SDGs. A detailed study like the one reported here was conducted on the integration of sustainable development goals in higher education institutions in Portugal. Their results showed that only a few courses explicitly address at least one SDG. These courses are mainly in master's degrees in sciences and in the areas of social sciences, humanities, and natural and environmental sciences. Interestingly, when the perceptions of higher education students about the SDGs were studied, the results showed that most students have heard of the SDGs and have habits and behaviors favorable to sustainability (sustainable competencies). When asked about the SD issues that concern them most, the majority are more concerned about climate change, actively contribute to sustainable development with reuse, reduction, and recycling practices, and participate in activities to promote environmental protection. In this well-designed study, it is also established that universities are mainly committed to the social dimension of 
sustainability, then the economic and institutional dimensions are considered, leaving the environmental dimension as the least developed. The study aims to provide guidance to support institutions in the transition process towards sustainability. This research work creates awareness so that higher education institutions can take responsibility and commit more to the SDGs $[12,14,18]$.

The University of Iceland is a case like the one reported here but in the context of implementing the inclusion of SKCs either in the course description text or in the learning outcomes. The study identifies competencies that should be fostered through university teaching and learning. The results showed that key competencies are assessed as crucial for sustainable development; the most relevant are three, those of systemic thinking, anticipatory thinking, and critical thinking. These results indicate that the University of Iceland appears to be on similar steps to other universities that are on the path of implementing the UN SDGs in policy and practice and increasingly focus their attention on the competencies that students must achieve as a result of their learning. Its study and intention sustain that the student acquires sustainable skills and concepts that will be used for a sustainable reality [17].

Our results indicate that the transformation of the concept of sustainability into a central axis of all academic programs gives students a highly demanding and current competence; and enables students to focus their knowledge on actions that lead to SD in any of its dimensions. Thus, education becomes the vehicle of transformation. An issue in development that has been deeply and seriously touched upon $[8,9,13,42]$ is the evaluation of sustainability competencies. That path is the one we must take to enter the global dynamic of the evaluation techniques and instruments that are the most suitable for educational experiences focused on the acquisition of sustainability competencies.

Author Contributions: Conceptualization, J.M.-H., V.L.-P. and P.C.; methodology, J.M.-H. and P.C.; software, J.M.-H.; validation, P.C.; formal analysis, J.M.-H.; investigation, J.M.-H., V.L.-P. and P.C.; resources, P.C.; data curation, J.M.-H.; writing-original draft preparation, J.M.-H., V.L.-P. and P.C.; writing-review and editing, J.M.-H., V.L.-P. and P.C; visualization, V.L.-P.; supervision, J.M.-H.; project administration, J.M.-H. and P.C.; funding acquisition, J.M.-H. All authors have read and agreed to the published version of the manuscript.

Funding: The authors would like to acknowledge the financial support of the Writing Lab., Institute for the Future of Education, Tecnologico de Monterrey, Mexico, in the production of this work.

Institutional Review Board Statement: Not applicable.

Informed Consent Statement: Not applicable.

Acknowledgments: The authors would like to acknowledge the technical support of Writing Lab., Institute for the Future of Education, Tecnologico de Monterrey, Mexico, in the production of this work. The design templates of Figures 1 and 2 were created by Slidesgo, including icons by Flaticon and infographics and images by Freepik.

Conflicts of Interest: The authors declare no conflict of interest.

\section{References}

1. Kuhlman, T.; Farrington, J. What is sustainability? Sustainability 2010, 2, 3436-3448. [CrossRef]

2. James, P. Urban Sustainability in Theory and Practice: Circles of Sustainability; Routledge: London, UK, 2014. [CrossRef]

3. Magee, L.; Scerri, A.; James, P.; Thom, J.A.; Padgham, L.; Hickmott, S.; Deng, H.; Cahill, F. Reframing social sustainability reporting: Towards an engaged approach. Environ. Dev. Sustain. 2012, 15, 225-243. [CrossRef]

4. World Commission on Environment and Development (WCED). Our Common Future; Oxford University Press: New York, NY, USA, 1987.

5. Barth, M.; Godemann, J.; Rieckmann, M.; Stoltenberg, U. Developing key competencies for sustainable development in higher education. Int. J. Sustain. High. Educ. 2007, 8, 416-430. [CrossRef]

6. Wiek, A.; Withycombe, L.; Redman, C.L. Key competencies in sustainability: A reference framework for academic program development. Sustain. Sci. 2011, 6, 203-218. [CrossRef]

7. Barth, M.; Rieckmann, M. Academic staff development as a catalyst for curriculum change towards education for sustainable development: An output perspective. J. Clean. Prod. 2012, 26, 28-36. [CrossRef] 
8. Rieckmann, M. Future-oriented higher education: Which key competencies should be fostered through university teaching and learning? Futures 2012, 44, 127-135. [CrossRef]

9. Brundiers, K.; Wiek, A. Beyond Interpersonal Competence: Teaching and Learning Professional Skills in Sustainability. Educ. Sci. 2017, 7, 39. [CrossRef]

10. Vincent, S.; Rao, S.; Fu, Q.; Gu, K.; Huang, X.; Lindaman, K.; Mittleman, E.; Nguyen, K.; Rosenstein, R.; Suh, Y. Scope of Interdisciplinary Environmental, Sustainability, and Energy Baccalaureate and Graduate Education in the United States; National Council for Science and the Environment: Washington, DC, USA, 2017.

11. Johnson, E.; Edwards, D.; Simon, J. The Falk School of Sustainability and Environment; Chatham University: Pittsburgh, PA, USA, 2019.

12. Aleixo, A.M.; Azeiteiro, U.; Leal, S. The Implementation of Sustainability Practices in Portuguese Higher Education Institutions. Int. J. Sustain. High. Educ. 2018, 19, 146-178. [CrossRef]

13. Cebrián, G.; Segalàs, J.; Hernández, À. Assessment of sustainability competencies: A literature review and pathways for future research and practice. Cent. Eur. Rev. Econ. Manag. 2019, 3, 19-44.

14. Aleixo, A.M.; Azeiteiro, U.; Leal, S. Are the sustainable development goals being implemented in the Portuguese higher education formative offer? Int. J. Sustain. High. Educ. 2020, 21, 336-352. [CrossRef]

15. Birdman, J.; Redman, A.; Lang, D.J. Pushing the boundaries: Experience-based learning in early phases of graduate sustainability curricula. Int. J. Sustain. High. Educ. 2020, 22, 237-253. [CrossRef]

16. Aleixo, A.M.; Leal, S.; Azeiteiro, U.M. Higher education students' perceptions of sustainable development in Portugal. J. Clean. Prod. 2021, 327, 129429. [CrossRef]

17. Redman, A.; Wiek, A.; Barth, M. Current practice of assessing students' sustainability competencies: A review of tools. Sustain. Sci. 2021, 16, 117-135. [CrossRef]

18. Pálsdóttir, A.; Jóhannsdóttir, L. Key Competencies for Sustainability in University of Iceland Curriculum. Sustainability 2021, 13, 8945. [CrossRef]

19. United Nations. Transforming Our World: The 2030 Agenda for Sustainable Development. 2015. Available online: https: / /sdgs.un.org/2030agenda (accessed on 12 December 2021).

20. Schwab, K. The Fourth Industrial Revolution; Crown Publishing: New York, NY, USA, 2016.

21. Membrillo-Hernández, J.; Ramírez-Cadena, M.D.J.; Ramírez-Medrano, A.; García-Castelán, R.M.G.; García-García, R. Implementation of the challenge-based learning approach in Academic Engineering Programs. Int. J. Interact. Des. Manuf. 2021, 15, 287-298. [CrossRef]

22. United Nations Educational, Scientific and Cultural Organization, UNESCO. Issues and Trends in Education for Sustainable Development; UNESCO: Paris, France, 2018.

23. Membrillo-Hernandez, J.; Garcia-Garcia, R. Challenge-Based Learning (CBL) in Engineering: Which evaluation instruments are best suited to evaluate CBL experiences? In Proceedings of the 2020 IEEE Global Engineering Education Conference (EDUCON). In Proceedings of the 2020 IEEE Global Engineering Education Conference (EDUCON), Porto, Portugal, 27-30 April 2020. [CrossRef]

24. Tay, H.Y. Setting formative assessments in real-world contexts to facilitate self-regulated learning. Educ. Res. Policy Prac. 2015, 14, 169-187. [CrossRef]

25. Membrillo-Hernández, J.; de J. Ramírez-Cadena, M.; Caballero-Valdés, C.; Ganem-Corvera, R.; Bustamante-Bello, R.; BenjamínOrdoñez, J.A.; Elizalde-Siller, H. Challenge based learning: The case of sustainable development engineering at the Tecnologico de Monterrey, Mexico City campus. In Advances in Intelligent Systems and Computing; Springer: Cham, Switzerland, 2018; pp. 908-914. [CrossRef]

26. Membrillo-Hernández, J.; Ramírez-Cadena, M.J.; Martínez-Acosta, M.; Cruz-Gómez, E.; Muñoz-Díaz, E.; Elizalde, H. Challenge based learning: The importance of world-leading companies as training partners. Int. J. Interact. Des. Manuf. 2019, 13, 1103-1113. [CrossRef]

27. Wiek, A.; Withycombe, L.; Redman, C.; Mills, S.B. Moving Forward on Competence in Sustainability Research and Problem Solving. Environ. Sci. Policy Sustain. Dev. 2011, 53, 3-13. [CrossRef]

28. Cato, M.S.; Myers, J. Education as re-embedding: Stroud communiversity, walking the land and the enduring spell of the sensuous. Sustainability 2011, 3, 51-68. [CrossRef]

29. Rosen, M.A. Engineering sustainability: A technical approach to sustainability. Sustainability 2012, 4, 2270-2292. [CrossRef]

30. Wiek, A.; Farioli, F.; Fukushi, K.; Yarime, M. Sustainability science: Bridging the gap between science and society. Sustain. Sci. 2012, 7, 1-4. [CrossRef]

31. Brundiers, K.; Wiek, A. Do we teach what we preach? An international comparison of problem- and project-based learning courses in sustainability. Sustainability 2013, 5, 1725-1746. [CrossRef]

32. Sandoval, J.; Ortiz, a.; Rodriguez, J. The Added Value of Integrating the Academia in Energy Efficiency Learning Networks. In Proceedings of the World Sustainable Energy Days, Young Energy Researchers Conference, WSED2019, Wells. Available online: https:/ / www.wsed.at/reviews/wsed-2019/young-energy-researchers-conference-2019 (accessed on 12 December 2021).

33. Ariguznaga-Urquidy, J.M.; Duek-Kalach, M.; Javier-Alvarado, L. Engineering in Sustainable Development: An Innovative Academic Program. In Proceedings of the World Conference on Continuing Engineering Education, IACEE2021, Trondheim, Norway, May 2021. Available online: https:/ /iacee2021.org/proceedings/ (accessed on 12 December 2021). 
34. Caratozzolo, P.; Membrillo-Hernández, J. Evaluation of Challenge Based Learning Experiences in Engineering Programs: The Case of the Tecnologico de Monterrey, Mexico. In Visions and Concepts for Education 4.0. ICBL 2020. Advances in Intelligent Systems and Computing; Auer, M.E., Centea, D., Eds.; Springer: Cham, Switzerland, 2021; Volume 1314. [CrossRef]

35. Available online: https:// observatory.itesm.mx/Tec21/ (accessed on 31 October 2021).

36. Caratozzolo, P.; Friesel, A.; Randewijk, P.; Navarro-Duran, D. Virtual Globalization: An Experience for Engineering Students in the Education 4.0 Framework. In Proceedings of the 2021 ASEE Virtual Annual Conference Content Access, Virtual Conference, 2021; Available online: https:/ / peer.asee.org/38016 (accessed on 12 December 2021).

37. Almeida, F.; Simoes, J. The role of serious games, gamification and industry 4.0 tools in the education 4.0 paradigm. Contemp. Educ. Technol. 2019, 10, 120-136. [CrossRef]

38. Demartini, C.; Benussi, L. Do web 4.0 and industry 4.0 imply education X.0? IT Prof. 2017, 19, 4-7. [CrossRef]

39. Salmon, G. May the fourth be with you: Creating Education 4.0. J. Learn. Dev. 2019, 6. Available online: https://jl4d.org/index. $\mathrm{php} /$ ej14d/article/view/352 (accessed on 12 December 2021).

40. Bartolomé, A.; Castañeda, L.; Adell, J. Personalisation in educational technology: The absence of underlying pedagogies. Int. J. Educ. Technol. High. Educ. 2018, 15, 14. [CrossRef]

41. Mendoza, J.M.F.; Schmid, A.G.; Azapagic, A. Building a business case for implementation of a circular economy in higher education institutions. J. Clean. Prod. 2019, 220, 553-567. [CrossRef]

42. Cebrián, G.; Junyent, M.; Mulà, I. Competencies in education for sustainable development: Emerging teaching and research developments. Sustainability 2020, 12, 579. [CrossRef] 